Syntax Literate: Jurnal Ilmiah Indonesia p-ISSN: 2541-0849

e-ISSN: 2548-1398

Vol.6, No.10, Oktober 2021

\title{
DAMPAK PANDEMI COVID-19 TERHADAP PERILAKU MANAJEMEN KEUANGAN GENERASI MILENIAL
}

\section{Helman}

Universitas Prima Indonesia (UNPRI) Medan, Indonesia

Email: helmanharun@gmail.com

\begin{abstract}
Abstrak
Generasi milenial saat ini menjadi generasi yang medominasi usia produktif dan berperan besar pada era bonus demografi. Sebagai generasi dengan populasi terbasar, generasi milenial akan memegang kendali atas roda pembangunan khususnya dibidang ekonomi. Namun generasi milenial juga dikenal sebagai generasi yang konsumtif. Disisi lain, pandemi Covid-19 yang melanda dunia telah memberikan dampak diseluruh aspek kehidupan tak terkecuali aspek ekonomi. Ketiakpastian situasi dan kondisi selama pandemi telah memaksa msayarakat untuk bersikap adaptif, salah satunya melalui perilaku manjemen keuangan. Hasil penelitian ini menunjukkan bahwa generasi milenial dapat bersikap adaptif selama pandemi Covid-19, dimana tingkat konsumsi mereka berkurang dan dialihkan untuk kepentingan yang lebih mendesak. Selain itu, literasi keuangan generasi milenial mengalami peningkatan yang berdampak baik pada perilaku manajemen keuangannnya.
\end{abstract}

Kata Kunci: generasi milenial; manajemen keuangan; pandemi covid-19

\section{Abstract:}

The millenials is currently dominates the productive ages and plays a major role in the era of demographic bonus. As the generation with largest population, the millenials will take control of the "wheel of development", especially in the economic field. However, the millennials is also known as the consumptive generation. On the other hand, the Covid-19 pandemic has impacted every aspect of life, including the economic issues. The uncertainty of the situation and conditions during the pandemic has forced the society to be adaptive, one of which is through financial management behavior. The results of this study indicate that the millennials could be adaptive during the Covid-19 pandemic, where their consumption level is reduced and diverted for more urgent interests. In addition, the millennials financial literacy has increased which give a good impact on their financial management behavior.

Keywords: millennials; financial management; covid-19 pandemic

Received: 2021-09-20; Accepted: 2021-10-05; Published: 2021-10-20

$\begin{array}{ll}\text { How to cite: } & \text { Helman, H (2021) Dampak Pandemi Covid-19 Terhadap Perilaku Manajemen Keuangan Generasi } \\ & \text { Milenial. Syntax Literate: Jurnal Ilmiah Indonesia, 6(10). http://dx.doi.org/10.36418/ Syntax- } \\ & \text { Literate.v6i10.4369 } \\ \text { E-ISSN: } & \text { 2548-1398 } \\ \text { Published by: } & \text { Ridwan Institute }\end{array}$




\section{Pendahuluan}

Pandemi Covid-19 masih terus berlangsung hingga saat ini, bahkan mengalami lonjakan kasus positif sejak awal Januari 2021. Di Indonesia, kondisi pandemi Covid-19 juga tidak lebih baik dan semakin mengkhawatirkan. Hal ini dapat dilihat dari kasus aktif dan angka kematian yang terus bertambah. Per tanggal 30 Juli 2021 terjadi penambahan 41.168 kasus baru sehingga total akumulasi kasus positif menjadi 3.372.374 kasus positif terkonfirmasi terhitung sejak kasus pertama diumumkan Presiden Joko Widodo pada 2 Maret 2020. Dari total kasus tersebut, 2.730.720 dinyatakan sembuh dan 92.311 orang meninggal dunia (Fuentealba, González, Pérez, Tempo, \& Troncoso, 2021). Sejak pandemi Covid-19 mulai mewabah di Indonesia pada Maret 2020, pemerintah telah menerapkan berbagai kebijakan sebagai upaya untuk menekan penyebaran Covid-19 dengan cara membatasi pergerakkan masyarakat. Kebijakan tersebut terus berganti nama dan format seiring berjalannya waktu, dimulai dari PSBB (Pembatasan Sosial Berskala Besar), PSBB Transisi, PPKM Darurat hingga PPKM Empat Level (Fauziah, Hadi, Fadhlillah, \& Ramadhena, 2021). Kebijakan tersebut secara garis besar dilakukan dengan mengatur kegiatan dan jam operasional kegiatan masyarakat, mulai dari pusat-pusat perbelanjaan, kegiatan belajar mengajar, pembatasan tempat kerja hingga penutupan fasilitas umum dan kegiatan sosial budaya. Pembatasan ini pada akhirnya menyebabkan dampat besar terhadap aktivitas perekonomian masyarakat termasuk keberlangsungan pekerjaan dan penurunan pendapatan pekerja (Mundzir et al., 2021). Dampak pandemi Covid-19 signifikan terhadap perlambatan roda perekonomian Indonesia (Parulian \& Tan, 2021).

Wabah Covid-19 telah mempengaruhi berbagai aspek kehidupan masyarakat secara signifikan. Tidak hanya aspek kesehatan yang menjadi sangat rentan karena mudahnya penyebaran virus ini, namun aspek enonomi juga dianggap sebagai salah satu aspek yang sangat berdampak negatif (Arthi \& Parman, 2021). Menurut Ozili \& Arun (2020) gangguan ekonomi tiba-tiba yang disebabkan oleh Covid-19 tidak hanya merusak tetapi juga menyebabkan dampak berlebih karena menciptakan guncangan permintaan dan penawaran di hampir setiap bidang usaha. Berbagai kebijakan pembatasan aktivitas sosial masyarakat yang diberlakukan pemerintah seperti pembatasan transportasi, pusat perbelanjaan, wisata dan hiburan ditutup. Keadaan tersebut bedampak luas terhadap kondisi sosial dan ekonomi masyarakat termasuk keberlangsungan pekerjaan dan penurunan pendapatan kerja (Ngadi, Meliana, \& Purba, 2020).

Ketidakpastian situasi dan kekhawatiran akan penularan Covid-19 serta adanya himbauan untuk "stay at home" dan social distancing membuat masyarakat sangat berhati-hati dan membatasi aktivitas di luar rumah. Selain itu, dengan adanya pembatasan aktivitas sosial, sebagian pekerja juga ikut dirumahkan. Akibatnya kegiatan ekonomi menjadi sangat terbatas sehingga banyak bidang usaha mengalami kerugian. Bahkan banyak perusahaan dan lembaga yang secara perlahan menutup usaha mereka. Pemilik usaha terpaksa harus melakukan efisiensi dan melakukan hal yang bertentangan 
dengan prinsip ekonomi karena sejak pandemi berlangsung mereka harus mengurangi ruang untuk menjaga jarak fisik aman, salah satunya adalah dengan melakukan pemutusan hubungan kerja atau PHK (Müller \& Rau, 2021). Berdasarkan survei yang dilakukan oleh Pusat Penelitian Kependudukan LIPI bersama Kementerian Ketenagakerjaan dan Lembaga Demografi Universitas Indonesia (LD-UI) pada tahun 2020, jumlah tenaga kerja yang ter-PHK mencapai 15,6\% bahkan 13,8\% tidak mendapatkan pesangon. Lebih lanjut, survei tersebut menunjukkan bahwa terjadinya PHK yang sangat besar pada tenaga kerja dengan rentang usia 15-44 tahun (Ngadi et al., 2020).

Indonesia pada saat ini diasumsikan sedang berada di era bonus demografi. Bonus demografi merupakan keadaan rasio jumlah penduduk usia tidak produktif lebih kecil dibandingkan dengan jumlah penduduk yang berusia produktif. Usia tidak produktif adalah seseorang yang berusia dibawah 15 tahun dan di atas 65 tahun, sedangkan yang dimaksud usia produktif adalah mereka yang berusia diantara 15-64 tahun. Menurut Badan Pusat Statistik (2020), kategori penduduk Indonesia usia produktif berjumlah 181 juta jiwa dan penduduk usia tidak produktif berjumlah 86 juta jiwa. Hal ini menunjukkan bahwa Indonesia memang sedang mengalami era bonus demografi. Lebih lanjut menurut BPS (2020), dari 181 juta penduduk dengan usia produktif jumlah generasi milenial sebesar 69,9 juta jiwa sehingga dapat disimpulkan bahwa generasi milenial adalah generasi yang mendominasi usia produktif dan berperan besar pada era bonus demografi. Sebagai penduduk terbesar, generasi milenial akan memegang kendali atas roda pembangunan khususnya dibidang ekonomi.

Menurut Badan Pusat Statistik (2018) dalam buku Statistik Gender Tematik: Profil Generasi Milenial Indonesia, generasi milenial atau generasi Y adalah mereka yang lahir diantara tahun 1980 sampai dengan 2000 atau mereka yang saat ini berusia 20 - 40 tahun. Generasi milenial dikenal sebagai generasi yang percaya diri, modern, ekspresif, berpikir liberal, terbuka terhadap inovasi, suka tantangan dan dimanjakan dengan kepraktisan dimana generasi ini bertumbuh seiring dengan berkembangnya tekonologi (Cwynar, 2020). Generasi milenial melibatkan teknologi dalam segara aspek kehidupan dimana hal ini dapat dilihat dari hampir seluruh individu dalam generasi tersebut. Selain itu, generasi milenial dikenal selalu mengikuti trend yang sedang terjadi di lingkungannya. Menurut IDN Times (2019) generasi milenial memiliki pemikiran yang menarik dan kreatif serta berani menghadapi resiko, akan tetapi generasi ini juga dikenal sangat konsumtif. Berdasarkan hasil survei yang dilakukan IDN Research Institute (2019), mayoritas pengeluaran generasi milenial adalah untuk keperluan rutin dengan persentase $51,1 \%$. Mereka hanya dapat menyisihkan uangnya untuk tabungan sebesar 10,7\%, sementara untuk entertainment atau hiburan sebesar 8 persen dimana jumlah tersebut hampir menyamai jumlah tabungan. Selain itu, mereka hanya dapat menyisihkan 2 persen untuk investasi. Survey tersebut menyimpulkan bahwa generasi milenial merupakan generasi yang konsumtif dalam penggunaan uangnya, pengeluaran mereka membutuhkan banyak anggaran dan sebagian besar belum mengetahui jumlah yang harus mereka simpan untuk masa depan mereka. Menurut (Ordun, 2015), perilaku 
konsumtif generasi merupakan akibat dari kemajuan teknologi, dimana perlaku konsumtif tersebut bergantung pada informasi yang didapatkannya melalui gadget.

Sebagai generasi dengan populasi terbanyak dan diharapkan menjadi roda pemegang kendali pembangunan bangsa, generasi milenial masih belum sejalan dengan survei tersebut. Kendala yang dihadapi generasi milenial adalah perilaku keuangan mereka atau disebut juga perilaku manajemen keuangan. Perilaku manajemen keuangan merupakan kemampuan seseorang maupun organisasi dalam mengatur dan menyimpan keuangan sehari-hari. Perilaku ini penting untuk dikuasai agar individu maupun organisasi dapat menyeimbangkan pengeluaran dan pemasukan. Selain itu, perilaku ini dapat menghindarkan dan membantu apabila terjebak dalam masalah keuangan. Menurut (Faramitha, Wahyudi, \& Desmintari, 2021) perilaku manajemen keuangan dipengaruhi oleh literasi keuangan dan Locus of Control. Liteasi keuangan merupakan pemahaman dan kemampuan seseorang mengenai pengelolaan keuaannya (Mulyani, 2020). Kemampuan tentang bagaimana membuat keputusan keungan yang sehat merupakan keterampilan yang penting di dunia saat ini, tanpa memandang usia (Coşkuner, 2016). Menurut (Laily, 2016), Semakin tinggi tingkat literasi keuangan seseorang maka perilaku manajeman keuangannya juga akan semakin baik. Namun berdasarkan survey tingkat literasi keuangan yang dilakukan oleh Otoritas Jasa Keuangan pada tahun 2019 tingkat literasi keuangan Indonesia hanya sebesar 38,03 persen yang mana masih terbilang rendah (Mulasiwi \& Julialevi, 2020). Selain literesi keuangan, perilaku manajemen keuangan juga dipengaruhi oleh Locus of control (lokus pengendali) yang merupakan cara pandang seseorang terhadap kemampuannya dalam mengendalikan diri mereka untuk menentukan nasib pada fenomena atau situasi yang terjadi pada diri sendiri maupun lingkuangan (Keuangan, 2017).

Pandemi Covid-19 yang masih melanda dunia hingga saat ini telah merubah tatanan kehidupan individu dalan segala aspek kehidupannya termasuk aspek ekonomi. Seiring dengan perlambatan roda ekonomi, penghsailan individu maupun keluarga juga mengalami kesulitan dan hambatan keuangan. Sebagian besar masyarakat Indonesia tidak siap menghadapi krisis ekonomi yang disebabkan oleh pandemi Covid-19. Masalah yang dihadapi milenial pada masa pandemi Covid-19 adalah banyak sektor industri yang terdampak secara ekonomi, dimana para milenial bekerja, terdapat karyawan yang dirumahkan, kontrak yang tidak diperpanjang, pemotongan gaji, pemutusan hubungan kerja dan lain sebagainya yang pada akhirnya menyebabkan penghasilan para milenial berkurang, tertunda, bahkan tidak mendapatkan peghasilan selama beberapa bulan. Selain itu, penerapan kebiasaan baru dan tambahan pengeluaaran untuk biaya perlindungan diri (masker, handsanitizer, disinfektan), tes kesehatan (antigen, PCR) dan kebutuhan imun tubuh (vitamin, obat herbal dan medis) (Parulian \& Tan, 2021). Perubahan yang signifikan dalam perekonomian pada akhirnya berimbas pada pola perilaku keuangan yang ditunjukkan seseorang. Selain itu, kondisi yang yang disebabkan pandemi juga merubah perilaku konsumtif. Berdasarkan latar belakang tesebut, Penelitian ini bertujuan untuk mengidentifikasi dampak pandemi 
Covid-19 terhadap perubahan perilaku manajemen keuangan generasi milenial pada masa pandemi Covid-19.

\section{Metode Penelitian}

Penelitian ini menggunakan metode penelitian kepustakaan atau kajian literatur. Penelitian kepustakaan merupakakan penelitian yang mengambil sumber data dari berbagai literatur kepustakaan seperti buku, jurnal, dokumen, kamus, koran dan lain sebagainya. Kajian literatur merupakan metode meninjau secara kritis pengetahuan, gagasan atau temuan dalam sebuah pustaka dan merumuskan kontribusi teoritis serta metodologisnya untuk topik tertentu. Sifat dari penelitian in adalah analisis deskriptif yaitu penguraian secara teratur data yang telah diperoleh kemudian diberikan pemahaman dan penjelasan agar dapat dipahami dengan baik oleh pembaca.

\section{Hasil dan Pembahasan}

\section{Generasi Milenial}

Teori perbedaan generasi pertama kali diteliti oleh Manheim pada tahun 1952 dan dipopulerkan oleh Neil Howe dan William Strauss pada tahun 1991. Menurut (Mannheim, 1952) generasi adalah sebuah konstruksi sosial yang didalamnya terdapat sekelompok orang yang memiliki kesamaan umur dan pengalaman historis. Adapun individu yang menjadi bagian dari suatu generasi adalah mereka yang memiiki kesamaan tahun lahir dalam rentang waktu 20 tahun dan berada dalam dimensi sosial dan sejarah yang sama. Lebih lanjut (Strauss \& Howe, 1991) membagi generasi berdasarkan kesamaan rentang waktu kelahiran dan kesamaan kejadian-kejadian historis. Menurut sebagian besar definisi para ahli, interval setiap generasi adalah 20 tahun, dimana Interval tersebut mewakili rentang rata-rata waktu antara kelahiran anak dan awal generasi baru. Interval 20 tahun juga mewakili pembagain rata-rata usia manusia yaitu 80 tahun ke dalam empat fase kehidupan; muda, naik dewasa, paruh baya dan lanjut usia (Strauss \& Howe, 1991). Terbentuknya pengelompokkan generasi diawali oleh gagasan bahwa generasi merupakan sekelompok individu yang dipengaruhi oleh kejadian-kejadian bersejarah serta fenomena budaya yang terjadi pada fase kehidupan mereka. Hal tersebut menyebabkan terbentuknya ingatan secara kolektif yang kemudian berdampak pada terbentuknya perilaku individu, nilai dan kepribadian (Putra, 2017).

Pembagian generasi telah banyak dikemukakan oleh banyak peneliti lain dengan label dan rentang waktu yang berbeda-beda, namun secara umum memiliki makna yang sama. Menurut (Strauss \& Howe, 2000) menyebutkan bahwa ganerasi milenial adalah generasi yang dilahirkan pada tahun 1982-2000. Sementara menurut (Martin \& Tulgan, 2002), generasi milenial adalah generasi yang dilahirkan pada tahun 1978 - 2000. Dalam Buku Statistik Gender Tematik: Profil Generasi Milenial Indonesia 2018 generasi milenial atau generasi Y Indonesia adalah mereka yang dilahirkan pada tahun 1980 sampai dengan 2000. Sebelum generasi milenial ada generasi X yang menurut para peneliti adalah mereka yang lahir pada tahun 1960 - 1980 . 
Generasi ini cenderung menyukai risiko dan cenderung mengambil keputusan yang matang akibat dari pola asuh generasi sebelumnya yaitu generasi Baby Boomers. Generasi Baby Boomers adalah generasi yang lahir pada tahun 1946-1960.

Ciri utama generasi milenial atau yang disebut juga dengan generasi Y adalah adanya peningkatan penggunaan teknologi komunikasi instan seperti email, SMS, instan messaging dan media sosial seperti facebook, twitter dan instagram. Adapun ciri-ciri lain dari generasi $\mathrm{Y}$ adalah setiap individu memiliki karakteristik yang berbeda-beda tergantung dimana ia dibesarkan, strata ekonomi dan sosial keluarganya, pola komunikasi yang sangat terbuka dibandingkan generasi-generasi sebelumnya, fanatik dalam bermedia sosial dan sangat dipengaruhi perkembangan teknologi, lebih terbuka dengan pandangan politik dan ekonomi sehingga menjadi sangat reaktif terhadap perubahan lingkungan yang terjadi di sekelilingnya, dan memiliki perhatian yang lebih terhadap kekayaan.

2. Perilaku manajemen keuangan

Perilaku manajemen keuangan merupakan perolehan, alokasi, dan penggunaan sumber daya keuangan yang berorientasi pada beberapa tujuan (Topa, HernándezSolís, \& Zappalà, 2018). Menurut (Al Kholilah \& Iramani, 2013), perilaku manajemen keuangan adalah kemampuan seseorang dalam mengatur dana keuangan sehari-hari, yang terdiri dari perencanaan, penganggaran, pemeriksaan, pengelolaan, pengendalian, pencarian dan penyimpanan keuangan. Perilaku manajemen keuangan terbagi menjadi tiga hal utama yaitu konsumsi, tabungan dan investasi. Perilaku keuangan yang baik dapat terlihat dari kegiatan perencanaan, pengelolaan dan kontrol kuangan yang sehat. Munculnya perilaku manajemen keuangan merupakan dampak dari besarnya keinginan seseorang untuk memenuhi kebutuhan hidup sesuai dengan tingkat pendapatnya (Erlangga \& Krisnawati, 2020). Seseorang yang bertanggungjawab dalam mengelola keuangannya cenderung lebih efektif dalam memanfaatkan uang yang dimilikinya dengan cara menyusun anggaran, menghemat uang, mengendalikan belanja, berinvestasi, serta membayar tagihan dan utang tepat waktu (Pulungan, 2021).

Menurut penelitian Mien dan Thao (2015) faktor-faktor yang mempengaruhi perilaku manajemen keuangan pada generasi muda usia 19-30 tahun antara lain sikap keuangan, pengetahuan keuangan, dan locus of control. Selain itu, menurut (Faramitha et al., 2021) perilaku manajemen keuangan dipengaruhi oleh literasi keuangan dan locus of control (lokus pengendali). Adapaun menurut (Sina, 2014), kepribadian merupakan salah satu faktor yang mampu mempengaruhi perilaku manajemen keuangan seseorang secara signifikan. Literasi kuangan merupakan pengetahuan seseorang dalam mengelola keuangan yang mencakup berbagai aspek antara lain penyimpanan, pinjaman, konsumsi, dan investasi (Chen \& Volpe, 1998). Literasi kuangan dapat memberikan dampak positif terhadap kesejahteraan individu dimana pengetahuan keuangan tersebut akan menentukan perilaku individu dalam mengambil keputusan (Ningtyas, 2019). Menurut (Parulian \& Tan, 2021), kemampuan literasi keuangan yang didukung oleh perilaku dan sikap keuangan yang 
sehat dan baik dapat membantu mencapai tingkat kesejahteraan keuangan secara efektif. Selain itu, kemampuan literasi keuangan juga menunjukkan perilaku yang baik dalam mengelola keuangan dalam kondisi sebaik mungkin termasuk pada saat pandemi Covid-19. Selain literasi keuangan, perilaku manajemen keuangan juga dipengaruhi oleh aspek psikologis yaitu locus of control (lokus pengendali) yang merupakan kepercayaan seseorang mengenai apa penyebab dalam kehidupannya dan bagaimana seseorang memberikan respon sumber kejadian tersebut dari dalam atau dari luar individu tersebut (Rotter, 1966). Menurut Rotter, Locus of control dibagi menjadi menjadi locus of control internal dan eksternal. Locus of control internal akan mempengaruhi perilaku keuangan jika individu memiliki rasa percaya diri, merasa puas dan juga bekerja keras sedangkan locus of control eksternal dapat mempengaruhi perilaku keuangan jika tidak merasa beruntung, tidak ada inisiatif dan tidak suka bekerja keras. Secara khusus, LOC secara pasial memediasi pengaruh pengetahun keuangan dan pendapatan pada perilaku manajemen keuangan (Saepuloh, 2019).

3. Dampak Pandemi Terhadap Perubahan Perilaku Manajemen Keuangan Generasi Milenial di Masa Pandemi

Generasi milenial saat ini mendominasi angkatan kerja di Indonesia dengan porsi rata-rata 50 persen dari seluruh generasi usia di segala sektor (Sartika, Widyastuti, \& Sondari, 2021) Generai milenial memiliki pendapatan yang cukup besar namun juga terkenal lebih konsumtif dibandingkan generasi yang lain. Hal ini karena kebanyakan penghasilannya dihabiskan untuk memenuhi gaya hidup. Generasi milenial lebih banyak menghabiskan uang untuk konsumsi daripada menabung dan investasi sehingga mereka banyak yang terjebak dalam perilaku dan gaya hidup yang konsumtif (Azizah, 2020). Lebih lanjut menurut survei yang dilakukan IDN Research Institute (2019), mayoritas pengeluaran generasi milenial adalah untuk keperluan rutin dengan persentase 51,1 persen, diikuti tabungan sebesar 10,7 persen, entertainment atau hiburan sebesar 8 persen dan 2 persen untuk investasi. Hal ini terjadi karena masih rendahnya literasi keuangan generasi milenial Indonesia.

Pandemi Covid-19 mengakibatkan kekhawatiran dan kecemasan pada masyarakat dimana hal ini mendorong mereka untuk melakukan berbagi upaya untuk terhindar dari penyakit tersebut, salah satunya adalah dengan melakukan berbagai himabuan serta kebijakan yang dikeluarkan oleh pemerintah. Menurut penelitian yang dilakukan (Ramdani, Amri, Warsihna, Garnasih, \& Juarsa, 2021) pandemi memberikan dampak yang berbeda terhadap perilaku manajeman keuangan pada pegawai tetap dan pegawai kontrak. dimana pegawai kontrak memiliki rasa kekhawatiran yang berlebih karena ketikpastian nasib mereka dalam pekerjaan. Hal ini karena mereka kontrak kerjanya dapat diputuskan kapan saja oleh instansinya. Sementara pegawai tetap cenderung memiliki orientasi yang lebih kuat untuk masa depannya. Hal tersebut mengakibatkan perilaku manajemen keuangan yang berbeda dimana pekerja dengan status pekerjaan tetap cenderung tetap melakukan tindakan preventif seperti memperbanyak tabungan, berinvestasi, mengedepankan hal yang 
lebih penting dan lebih menghargai uang. Sementara itu pada pegawai kontrak perilaku kuangan mereka cenderung untuk memenuhi kebutuhan yang lebih mendesak dan sedikit berpikiran untuk menabung karena mereka dituntut untuk adaptif. namun, secara umum ketidakpastian Covid-19 menyebabkan perilaku keuangan yang lebih baik salah satunya adalah masyarakat cenderung lebih mengutamakan kebutuhan dibandingkan keinginan semata (Ramdani et al., 2021).

Perubahan situasi dan kondisi yang disebabkan pandemi juga berpengaruh terhadap perilaku konsumtif masyarakat. Menurut penelitian (Larasati, 2020) sejak pandemi Covid-19 berlangsung, terjadi perubahan konsumsi masyarakat sebelum dan sesudah pandemi dalam cakupan wilayah Kota Bandung. Penelitian tersebut mengemukakakn bahwa sebelum pandemi pola konsumsi masyarakat paling besar dialokasikan untuk keperluan fashion dan komunikasi yaitu 25 persen. Sementara untuk keperluan lain seperti transportasi 15\%, pendidikan 15 persen dan makanan 20 persen. Namun setelah pandemi konsumsi masyarakat paling besar yaitu makanan $30 \%$, pendidikan $15 \%$, komunikasi $5 \%$, transportasi $5 \%$, hiburan $15 \%$, fashion $10 \%$ dan laundry $20 \%$ (Larasati, 2020). Sementara itu, berdasarkan penelitian (Kurniasih, 2020) terjadi penurunan pendapatan pada masyarakat Pontianak antara 30\%-70\% sementara pengeluaran cenderung tetap. Mereka cenderung memilih untuk mencari sumber pendapatan lain agar dapat mempertahankan pola pengeluaran yang lama daripada mengubahnya. Meskipun demikian, masyarakat cenderung adaptif dan mengubah kebiasaan konsumtif yang lama.

Sebagai generasi yang akrab dengan perkembangan teknologi, generasi milenial memperlihatkan perilaku adaptif pada masa pandemi ini. Tidak hanya beradaptasi dengan rutinitas hariannya, tetapi mereka juga mampu memanfaatkan ide kreatif dan teknologi yang ada. Hal ini sejalan dengan penelitian (Manguma, 2021) dimana generasi milenial menerapkan berbagai strategi dalam upaya bertahan dan beradaptasi dengan perubahan dan ketidakpastian di masa pandemi. Mereka menggunakan strategi aktif yaitu memberdayakan potensi yang dimiliki sesuai keterampilan dan kapasitasnya, strategi pasif yaitu dengan hidup hemat dan strategi jejaring yaitu melalui pinjaman keluarga, lembaga pemberi pinjaman dan bantuan pemerintah). Adapun Langkah-langkah yang bisa diambil oleh generasi milenial dalam mengatur keuangan selama masa pandemi (Aulia, 2020):

a. Mengatur ulang pos pengeluaran. Selama situasi pandem Covid-19 masih berlangsung, menjaga kesehatan adalah hal utama yang harus dilakukan. Salah satu cara yang dapat dilakukan adalah dengan melakukan upaya pencegahan melalui penerapan protokol kesehatan sehingga akan ada beberapa hal yang harus ditambahkan ke dalam daftar belanja kebutuhan sehari-hari seperti masker, handsanitizer, disinfektan, dan vitamin. Untuk itu, perlu adanya evaluasi untuk pengeluaran dan mencari tahu kebutuhan apa yang bisa dihilangkan sementara waktu agar uang dapat dialokasikan untuk yang lebih penting.

b. Mengevaluasi jumlah pemasukan apakah cukup untuk menutupi kebutuhan baru.

c. Mencari penghasilan tambahan bila perlu 
Helman

d. Tunda investasi dan alihkan untuk dana darurat, dimaana dana darurat dapat menjadi penolong jika kondisi terburuk datang.

e. Menutup pos pengeluaran yang tidak dibutuhkan

f. Bijak dalam berbelanja, dan

g. Menghindari hutang.

\section{Kesimpulan}

Berdasarkan hasil dan pembahasan literatur dapat disimpulkan bahwa terjadi pola perilaku manajemen keuangan pada generasi milenial pada masa pandemi Covid-19. Berbagai ketidakpastian di masa pandemi memaksa generasi milenial yang dikenal sebagai generasi yang konsumtif untuk beradaptasi dengan kondisi keuangannya. Perilaku manajemen keuangan dipengaruhi oleh literasi keuangan dan locus of control. Semakin baik pengetahuan keuangan yang dimiliki maka akan memberikan dampak yang baik terhadap pengambilan keputusan dan pengelolaan keuangan, sehingganya perlu adanya peningkatan edukasi mengenai literasi keuangan sebagai upaya meningakatkan kemampuan masyarakat khususnya generasi milenial. 


\section{BIBLIOGRAFI}

Al Kholilah, Naila, \& Iramani, Rr. (2013). Studi financial management behavior pada masyarakat surabaya. Journal of Business and Banking, 3(1), 69-80. Google Scholar

Arthi, Vellore, \& Parman, John. (2021). Disease, downturns, and wellbeing: Economic history and the long-run impacts of COVID-19. Explorations in Economic History, 79, 101381. Google Scholar

Aulia, Yoosita. (2020). Pengelolaan Keuangan Bagi Generasi Milenial Di Era New Normal. Google Scholar

Azizah, Nurul Safura. (2020). Pengaruh literasi keuangan, gaya hidup pada perilaku keuangan pada generasi milenial. Prisma (Platform Riset Mahasiswa Akuntansi), 1(2), 92-101. Google Scholar

Chen, Haiyang, \& Volpe, Ronald P. (1998). An analysis of personal financial literacy among college students. Financial Services Review, 7(2), 107-128. Google Scholar

Coşkuner, Selda. (2016). Understanding factors affecting financial satisfaction: The influence of financial behavior, financial knowledge and demographics. Imperial Journal of Interdisciplinary Research, 2(5), 377-385. Google Scholar

Cwynar, Andrze. (2020). Financial literacy, behaviour and well-being of millennials in Poland compared to previous generations: The insights from three large-scale surveys. Review of Economic Perspectives, 20(3), 289-335. Google Scholar

Erlangga, Muchammad Yudha, \& Krisnawati, Astrie. (2020). Pengaruh Fintech Payment Terhadap Perilaku Manajemen Keuangan Mahasiswa. Jurnal Riset Manajemen Dan Bisnis, 15(1), 53-62. Google Scholar

Faramitha, Anggie, Wahyudi, Wahyudi, \& Desmintari, Desmintari. (2021). Analisis perilaku manajemen keuangan pada generasi milenial. INOVASI, 17(1), 19-29. Google Scholar

Fauziah, Gina, Hadi, Firdaus, Fadhlillah, Fikry, \& Ramadhena, Gilang. (2021). Ketahanan Keluarga Dalam Meminimalisir Perceraian Pada Masa Pandemi Covid-19 di Kecamatan Cengkareng. Mizan: Journal of Islamic Law, 5(2), 303314. Google Scholar

Fuentealba, Oscar, González, Hernán A., Pérez, Alfredo, Tempo, David, \& Troncoso, Ricardo. (2021). Superconformal Bondi-Metzner-Sachs Algebra in Three Dimensions. Physical Review Letters, 126(9), 91602. Google Scholar

Keuangan, Perilaku. (2017). Pengaruh Pendapatan, Lokus Pengendalian Dan Pengetahuan Keuangan Terhadap Perilaku Keuangan Pelaku Umkm Kecamatan 
Helman

Cinere. Google Scholar

Kurniasih, Erni Pacar. (2020). Dampak Pandemi Covid 19 Terhadap Penurunan Kesejahteraan Masyarakat Kota Pontianak. Prosiding Seminar Akademik Tahunan Ilmu Ekonomi Dan Studi Pembangunan, 277-289. Google Scholar

Laily, Nujmatul. (2016). Pengaruh literasi keuangan terhadap perilaku mahasiswa dalam mengelola keuangan. Journal of Accounting and Business Education, 1(4). Google Scholar

Larasati, Retno Anisa. (2020). Pola Konsumsi Mahasiswa Pulang Kampung Dan Masyarakat Pada Pandemi Covid-19 Di Kota Bandung. Jambura Economic Education Journal, 2(2), 90-99. Google Scholar

Manguma, Varian Valiant Ervic. (2021). Strategi Generasi Millenial Bertahan Hidup Dalam Masa Pandemi Covid-19. Emik, 4(1), 84-97. Google Scholar

Mannheim, Karl. (1952). The problem of a sociology of knowledge. Essays on the Sociology of Knowledge, 134-190. Google Scholar

Martin, Carolyn A., \& Tulgan, Bruce. (2002). Managing the generation mix: From collision to collaboration. Human Resource Development. Google Scholar

Mulasiwi, Cut Misni, \& Julialevi, Karina Odia. (2020). Optimalisasi Financial Teknologi (Fintech) Terhadap Peningkatan Literasi Dan Inklusi Keuangan Usaha Menengah Purwokerto. Performance: Jurnal Personalia, Financial, Operasional, Marketing Dan Sistem Informasi, 27(1), 12-20. Google Scholar

Müller, Stephan, \& Rau, Holger A. (2021). Economic preferences and compliance in the social stress test of the COVID-19 crisis. Journal of Public Economics, 194, 104322. Google Scholar

Mulyani, Ika. (2020). Determinan Perilaku Manajemen Keuangan UMKM Binaan Bank Indonesia Provinsi DKI Jakarta. Konferensi Riset Nasional Ekonomi, Manajemen, Dan Akuntansi I. Google Scholar

Mundzir, A., Riorini, Sri Vandayuli, Indarti, Stefani Lily, Chanifah, Siti, Yulistiyono, Agus, Mayratih, Siska, Mulyono, Sri, Karyani, Etikah, Suryanto, Henri, \& Kusumawati, Indah. (2021). Peningkatan Ekonomi Masyarakat menuju Era Society 5.0 Ditengah Pandemi Covid-19. Penerbit Insania. Google Scholar

Ngadi, Ngadi, Meliana, Ruth, \& Purba, Yanti Astrelina. (2020). Dampak pandemi Covid-19 terhadap PHK dan pendapatan pekerja di Indonesia. Jurnal Kependudukan Indonesia, 43-48. Google Scholar

Ningtyas, Mega Noerman. (2019). Literasi Keuangan pada Generasi Milenial. Jurnal Ilmiah Bisnis Dan Ekonomi Asia, 13(1), 20-27. Google Scholar 
Ordun, Guven. (2015). Millennial (Gen Y) consumer behavior their shopping preferences and perceptual maps associated with brand loyalty. Canadian Social Science, 11(4), 40-55. Google Scholar

Parulian, Parulian, \& Tan, Emmelia. (2021). Peran Penyerapan Literasi Keuangan Terhadap Kesejahteraan Keuangan Generasi Milenial pada Masa Pandemi Covid19. Jurnal Pengembangan Wiraswasta, 23(2), 135-148. Google Scholar

Pulungan, Delyana Rahmawany. (2021). Analisis Perilaku Keuangan Mahasiswa Yang Dipengaruhi Oleh Literasi Keuangan Dan Pendapatan Orang Tua. Scenario (Seminar of Social Sciences Engineering and Humaniora), 162-173. Google Scholar

Putra, Yanuar Surya. (2017). Theoritical review: Teori perbedaan generasi. Among Makarti, 9(2). Google Scholar

Ramdani, Zulmi, Amri, Andi, Warsihna, Jaka, Garnasih, Titi Ratna, \& Juarsa, Eka. (2021). Perilaku manajemen keuangan karyawan selama pandemi COVID-19: sebuah studi awal. Eqien: Jurnal Ekonomi Dan Bisnis, 8(1), 170-179. Google Scholar

Rotter, Julian B. (1966). Generalized expectancies for internal versus external control of reinforcement. Psychological Monographs: General and Applied, 80(1), 1. Google Scholar

Saepuloh, Asep. (2019). Peran Mediasi Locus of Control pada Perilaku Keuangan. Manajerial, 6(2), 64-100. Google Scholar

Sartika, Dina, Widyastuti, Arie, \& Sondari, Mery Citra. (2021). Literasi Keuangan Bagi Generasi Millennial Di Era Pandemi Covid-19. Dharma Bhakti Ekuitas, 5(2), 535-542. Google Scholar

Sina, Peter Garlans. (2014). Tipe Kepribadian Dalam Personal Finance. Jurnal Jibeka, 8(1), 54-59. Google Scholar

Strauss, William, \& Howe, Neil. (1991). Generations: The history of America's future, 1584 to 2069. Quill New York. Google Scholar

Strauss, William, \& Howe, Neil. (2000). Millennials rising: The next great generation. Vintage Books New York. Google Scholar

Topa, Gabriela, Hernández-Solís, Montserrat, \& Zappalà, Salvatore. (2018). Financial Management behavior among young adults: The role of Need for Cognitive Closure in a three-wave moderated mediation model. Frontiers in Psychology, 9, 2419. Google Scholar

\section{Copyright holder:}

Helman (2021) 
Helman

First publication right:

Syntax Literate: Jurnal Ilmiah Indonesia

This article is licensed under:

(cc) (i) (O) 